\title{
Distance Lectures in University Studies: Advantages, Disadvantages, Improvement
}

\author{
Vincentas Lamanauskas \\ Vilnius University Šiauliai Academy, Lithuania \\ ORCID: 0000-0002-4130-7899 \\ Rita Makarskaitè-Petkevičienè \\ Vilnius University, Institute of Educational Sciences, Lithuania \\ ORCID: 0000-0003-1653-8094
}

Received: 1 Mar 2021

Accepted: 12 Apr 2021

\begin{abstract}
Distance learning is not a new subject in university study practice. It is clear that a significant number of universities practiced this way of learning before the pandemic. In the case of distance learning, the emphasis is always not so much on the means used for teaching and learning, as on the very fact of the physical separation of the lecturer and the student. There is a reasonable concern about the quality of studies, their efficiency, the quality of the qualifications acquired by future specialists, etc. The new context creates the need to analyse and assess the distance learning situation that arose during the pandemic.

In January-February 2021, a qualitative study was conducted, in which 158 students from three Lithuanian universities participated. Most of the respondents were students of social and humanitarian study programmes. Qualitative data obtained on the basis of open-ended questions were analysed using the method of quantitative content analysis, i.e., semantic subcategories and categories according to four main variables were distinguished: advantages of distance lectures, disadvantages of distance lectures, and distance lecture improvement.

It has been established that the main advantages are the convenience of studying and the flexibility of the study process. Meanwhile, the most obvious shortcomings are deterioration of physical and mental health and non-realisation of social needs, deterioration of the quality of academic activities. Improving the design of lectures and improving their planning and organisation are considered the key areas of improvement.
\end{abstract}

Keywords: content analysis, distance learning, distance lectures, qualitative research, university students

\section{INTRODUCTION}

It is understandable that distance learning is one of university study methods, when teaching and learning take place at a different time in different places, and ICT use creates a particular learning environment and ensures the teaching/learning process. It is also clear that not all study programmes can be carried out online. Various research shows that distance lectures can be an effective way of studying. Researchers reasonably notice that distance learning has become the most rapidly growing segment of higher education (Zaborova et al., 2017), e.g., a study conducted in Lithuania in 2012 showed that distance lectures had obvious advantages: students had a possibility to deepen their information technology knowledge at a convenient time, unable to participate in regular lectures due to illness or other reasons, could examine the lecture 
material independently, etc. (Stankūnienè, 2012). Researchers accentuate that distance learning is inevitable (Samašonok \& Žonych, 2020), however, despite of this it faces a variety of challenges. It is known that distance learning can be carried out applying synchronous, asynchronous, and mixed approaches. It is without doubt that the current level of information communication technologies and their variety and availability, provide many and various distance teaching/learning opportunities. Various previous research studies show that the application of distance teaching technologies increases teaching/learning efficiency (Konariovas, 2014), availability/ accessibility (Navickienè \& Vainorytè, 2015), learning to learn competence is improved (Rutkauskienè \& Pociūtè, 2006), digital competence (Torres-Gastelu, 2021) and other.

Retrospectively, there are quite a lot of research studies showing negative distance learning aspects as well. The research carried out in the USA showed that the students, attending distance teaching courses, demonstrated significantly weaker motivation for studies than the students attending regular lectures (Qureshi et al., 2002). Borisova et al. (2016) research showed that modern distance teaching methods for students are ineffective, therefore, a special role working with various technologies should be devoted to a lecturer. Australian researchers noticed that country universities are encouraged to carry out distance teaching, however there are critical success factors for this, which are not fully analysed and understood (Wu et al., 2015), besides, students' demographic peculiarities can have influence on distance teaching technology choice. Various newest research studies conducted in different countries demonstrate both positive and negative aspects of the phenomenon. The research carried out in Slovakia showed that distance education was closely related to emotions (and changes in emotions) and personality (Ballova Mikuškova, \& Verešova, 2020). The research carried out in Germany showed that teachers were experiencing significantly more stress than working in a usual way (Klapproth et al., 2020). The research conducted in Russia showed that the most frequent barriers in distance teaching were lack of necessary skills to apply computer based online learning systems, the inability to communicate with lecturers and insufficient support for distance learners (Leontyeva, 2018). Likewise, research shows that distance lectures have obvious advantages. A positive effect is observed when performing students' independent work using information technology (Atadjanov, 2020). Various electronic means are used to keep students in touch with teachers, a perfect possibility is provided for students to communicate with each other and so on. According to Sadeghi (2019), opportunities are created for the free distribution of teaching materials during distance learning activities. Finally, the new generation is quite familiar with technologies and therefore, they are not fully satisfied with conventional teaching/learning methods.

It is obvious that the new digital learning environment created by the internet offers a lot of exciting opportunities for distance learning students. As researchers (Brown et al., 2015) note, the life of distance learners is neither "black" nor "white", a lot of factors developing personal learning experience and providing support for students have to be taken into consideration. It is also understandable that distance learning has obvious advantages and disadvantages, therefore, proper organisation and management of the distance learning process can guarantee the success of such learning.

\section{Research Context, Aim, Questions}

However, the global pandemic caused by COVID-19, has fundamentally created different conditions and opportunities. Practically, the global transition to distance learning has become a serious challenge for university lecturers and students. During a relatively short period of time, the content of lectures, practical and laboratory works had to be adapted to online teaching, various technological challenges had to be solved, and high-quality lecturers had to be ensured in the changed conditions. In other words, the pandemic forced all educational institutions to switch to distance learning (Tuychieva et al., 2020), which in turn became a catalyst for some rapid changes in university studies.

This research was conducted in pandemic conditions when the study process in universities was transferred to online format. Lecturers and students were forced to change face-to-face teaching/learning to web-based distance teaching/learning (Louis-Jean \& Cenat, 2020). It is obvious, that distance teaching and learning definitely poses some serious challenges. The term "distance lectures" used in the research basically covers all study process - lectures, discussions, seminars, practical works, consultations, and other activities that are 
conducted online (both synchronously and asynchronously). This is a common term from organisationalmanagement point of view, when we talk about the study process organisation (e.g., the lecture schedule is created, etc.).

Distance learning can be understood as a way, form or strategy of teaching. In general, there is no one universally accepted definition of "distance learning”. Distance learning as a phenomenon in world practice has more than one term and even more different definitions (for example, distance teaching would be a more accurate concept, because education usually includes two sides - teaching and learning). For example, in addition to the very common term 'distance learning', other terms are used, such as 'remote learning', 'online learning', 'virtual learning', 'flexible learning', 'correspondence learning', etc. The main and essential common feature of distance teaching/learning is one - the physical separation of lecturer and student in space. Therefore, another essential thing is needed - the use of media and ICT to enable the communication necessary for the study process. The term "distance lectures" is closer to the concept of "organization of the study process at a distance". The universal transition to a different kind of education was not planned in advance by anyone, it is carried out under unusual, extreme conditions (COVID-19 pandemic).

Distance learning, the place and time of which do not usually coincide with the study process, requires special course delivery and teaching methodologies, special communication and information technology skills, techniques and special organizational and administrative preparation.

Conventional (regular) distance learning is based on the student's ' independent work at any place and at any time appropriate to the student. Meanwhile, the current research was conducted using a different model. All lectures took place in real time, according to a schedule. The difference was that lecturers and students met on the MS Teams platform rather than in university auditoriums. In this way, it was possible to use questions-answers, discussions or group work (by creating different rooms / channels) and various other methods directly. Students had the opportunity to listen to their friends, oppose them, etc., which would not be possible under conventional distance learning conditions, as students would work in their own mode and perhaps only occasionally meet in forums, etc.

It is obvious that, for those studying natural and technical sciences, distance learning during the pandemic prevented them from doing practical, laboratory work in laboratories, and this undoubtedly affected the quality of studies. And those studying social sciences escaped this difficult situation, for example, students of primary education study programme conducted some inquiry-based practical activities independently at home and presented the research results and evidence of research activities (for example, short videos) to their friends during remote meetings. So, learning from each other, discussing successes and areas for improvement they still had the opportunity.

Another important aspect is the lecturer and student meeting. During regular distance teaching/learning, it is minimal, uncommon, usually in the form of consultations. Under the pandemic conditions, the meetings took place as scheduled, although those meetings moved to the MS Teams platform, but the students heard the lecturer's "live" word, saw him and his friends on the screen, asked the lecturer questions, received answers, and so on.

Thus, the research aim was to ascertain basic distance lecture advantages, disadvantages, improvement possibilities. There are very few studies in Lithuania dealing with these questions. On the other hand, students' preferences and positions in the learning process, their teaching and information processing methods are important trying to achieve quality in the study process (Berkova et al., 2020).

It was sought to answer such research questions:

- What are advantages of distance lectures?

- What are disadvantages of distance lectures?

- What, how and what spheres could be improved? 


\section{RESEARCH METHODOLOGY}

\section{General Characteristics}

This qualitative research was carried out in January-February 2021. Such research is specifically recognized as "basic or generic qualitative research" (Merriam, 1998), because it has the essential characteristics of qualitative research. On the other hand, such research creates possibilities to obtain data about the phenomenon being studied or the phenomenon's possible new aspects (Bitinas, 2002). The conducted research is a part of a larger study that is targeting the subjective perceptions of students about online lectures.

\section{Research Sample}

The study involved 158 students from three Lithuanian universities. Evaluating Morse's (1994) recommendations, the sample of 30-50 participants is suitable for such kind of research. Assessing the position of Creswell (1998), a range of 20-30 participants is acceptable for qualitative samples. In addition, it was taken into consideration that not many variables were analysed in the study, the analysed population was essentially homogeneous, and such sample size was considered appropriate (Neuman, 1997).

The main demographic information about the respondents is presented in Table 1.

Table 1. Demographic characteristics of the Lithuanian sample ( $\mathrm{n} / \%)$

\begin{tabular}{|c|c|c|c|c|c|c|c|}
\hline \multirow[t]{2}{*}{ Gender } & \multicolumn{3}{|c|}{ Female } & \multicolumn{4}{|c|}{ Male } \\
\hline & \multicolumn{3}{|c|}{$151(95.6)$} & \multicolumn{4}{|c|}{$7(4.4)$} \\
\hline \multirow[t]{2}{*}{ Study level } & \multicolumn{3}{|c|}{ Bachelor } & \multicolumn{4}{|c|}{ Master } \\
\hline & \multicolumn{3}{|c|}{$138(87.3)$} & \multicolumn{4}{|c|}{$20(12.7)$} \\
\hline \multirow[t]{2}{*}{ Study year } & B1 & B2 & B3 & B4 & B5 & M1 & $\mathrm{M} 2$ \\
\hline & $13(8.2)$ & $56(35.4)$ & 24 (15.2) & $17(10.8)$ & $28(17.7)$ & $11(7.0)$ & $9(5.7)$ \\
\hline
\end{tabular}

According to the study programmes, the majority of the respondents were the students in the field of social sciences: students from education management (17.1\%), primary and pre-school education (38.0\%), childhood pedagogy (34.2\%) and subject pedagogy, geography, English philology, chemistry study programme students $1.9 \%$ each (12 students). The other 5 respondents ( $0.6 \%$ each) represented German, Russian philology, history, maths, physics study programmes.

Due to the fact that it is a small-scale qualitative study, the research sample was formed in incomplete adherence to the principle of randomness. Students from three Lithuanian universities were included in the research sample: Šiauliai university $(n=50)$, Klaipeda university $(n=12)$, Vilnius university $(n=96)$. Thus, the researchers were of the opinion that, in principle, the sample of 158 students surveyed was appropriate, seeking to formulate reasonable conclusions.

The communication of the respondents was by e-mail. The aim of the conducted research was explained to the respondents, and the respondents were informed about the use of the collected information appropriateness. The participation in the research was completely voluntary.

\section{Instrument}

The respondents were presented three open questions-tasks:

- Please mention and explain some online lecture advantages comparing them with traditional lectures;

- Please mention and explain some online lecture disadvantages, comparing them with traditional lectures;

- Please give suggestions, how it would be possible to improve online lectures;

The presented questions were prepared exclusively for this research, were analysed separately, and do not form a separate measurement scale. 
The participants had the opportunity to freely express their position on each question in writing. The scope of the answers was not limited, it was requested to rely only on personal experience in distance learning. The researchers took the view that open-ended questions were important because they made it possible to learn unexpected information.

\section{Data Analysis}

The obtained research data were expressed in the form of free answers in writing. Later, the collected answers were coded. The researchers sought to find similarities, differences, and interrelationships between the segments of the text and to single out clear semantic units. Thus, the smallest component of the text, semantically different from the others, was considered to be the unit of analysis. In the initial stage, multiple reading of the text was performed. Subsequently, the grouping of the most recurring semantic units (the subdivision of subcategories) was performed. Semantically close subcategories were grouped into categories. Afterwards, the subcategory and category interpretation and substantiation was carried out. The researchers based content analysis on the calculation of features, which were important to the researcher, and which could be summarised. Devi-Prasad (2019) defined content analysis as reducing a large portion of words obtained through qualitative data in order to make meaning of the data.

A quantitative type of content analysis was chosen, where a code system is defined, and the calculation results are presented in the form of tables. It was sought to determine how the analysed phenomenon was perceived /understood by the respondent, reflecting on his/her experience, based on the researcher's presented questions. Assessing the position of Mayring (2002), it can be stated that content analysis is a valid method that allows to draw reliable conclusions, referring to the systematically analysed text (verbal data array). Such approach enables researchers to avoid subjective text interpretation and guarantees the objectivity of the analysis (Guščinskienè, 2002). In the content analysis, the resulting data are analysed in depth to allow for the generation of previously unfamiliar themes and dimensions (Yıldırım \& Şimşek, 2011). Before choosing the content analysis method, the researchers made sure that there was enough material for the research and that it was representative. Semantic unit separation and grouping was carried out independently by two researchers seeking in this way to guarantee the objectivity of the analysis. In addition, to ensure reliability, the data were encoded by two different researchers independently and calculated using Miles and Huberman's (1994) "Reliability = (Consensus) / (Consensus + Difference of Opinion) * 100" formula for consensus or determination of possible differences. A coefficient of coding compatibility between two researchers was .87 . In order to achieve a higher objectivity of the analysis, the results of the content analysis were discussed with two experts in the field, university lecturers. In this way, sufficient internal validity was ensured. Experts confirmed that the subcategories and categories identified correspond to the actual situation under study and the data collected, which is related to the accuracy of the study results (Cohen et al., 2000).

\section{RESEARCH RESULTS}

It was analysed what online lecture advantages are discerned by students. Four categories were singled out: The convenience of studying, Study process flexibility, Satisfaction with the studies and Improvement of the competencies. The results are presented in Table 2. 
Table 2. Online lecture advantages $N(\%)$

\begin{tabular}{|c|c|c|c|}
\hline Categories & Subcategories & Statements & $N(\%)$ \\
\hline $\begin{array}{l}\text { The } \\
\text { convenience } \\
\text { of studying }\end{array}$ & $\begin{array}{l}\text { Combination of work } \\
\text { and study } \\
77 \text { (27.1) }\end{array}$ & $\begin{array}{l}\text { Online lectures provide an opportunity to study for the people, who want to } \\
\text { save time (due to the tense rhythm of the day) or cannot physically come to } \\
\text { lectures }\end{array}$ & $42(14.9)$ \\
\hline \multirow[t]{12}{*}{$165(58.1)$} & & $\begin{array}{l}\text { Parallelly can carry out work functions, can participate in lectures, and do } \\
\text { another unstrained work }\end{array}$ & $15(5.3)$ \\
\hline & & One can easier combine work and studies & $10(3.5)$ \\
\hline & & $\begin{array}{l}\text { Online lectures provide students more opportunities to participate in lectures } \\
\text { because most students are working people and not always could participate in } \\
\text { contact lectures }\end{array}$ & $8(2.8)$ \\
\hline & & No need to take learning holidays at work & $2(0.7)$ \\
\hline & \multirow{5}{*}{$\begin{array}{l}\text { Combination of } \\
\text { participation in lectures } \\
\text { with the individual } \\
\text { needs }\end{array}$} & Possibility to study from any place, where I have computer and internet & $26(9.1)$ \\
\hline & & Possibility of "multitasking" when you can do more than one task at a time & $5(1.8)$ \\
\hline & & $\begin{array}{l}\text { It is much easier to combine your personal needs, activities (i.e., one can join the } \\
\text { lecture at any place and participate in it, the number of participating in lectures } \\
\text { increases) }\end{array}$ & $3(1.0)$ \\
\hline & & A possibility to participate in lectures both using a computer and a telephone & $3(1.0)$ \\
\hline & & We can study when we are ill, we do not have to miss lectures due to illness & $3(1.0)$ \\
\hline & $\begin{array}{l}\text { Financial savings } \\
32(11.3)\end{array}$ & $\begin{array}{l}\text { From a financial point of view, it is cheaper, because the journey or a room rent } \\
\text { do not cost, other expenses decrease }\end{array}$ & $32(11.3)$ \\
\hline & Time planning & It is easier to plan, manage time, stick to the daily routine & $12(4.2)$ \\
\hline & $16(5.6)$ & $\begin{array}{l}\text { Online studies allow planning one's own works, work performance time is more } \\
\text { exact }\end{array}$ & $4(1.4)$ \\
\hline $\begin{array}{l}\text { Study process } \\
\text { flexibility }\end{array}$ & $\begin{array}{l}\text { Lecture content } \\
\text { availability }\end{array}$ & $\begin{array}{l}\text { Online lectures can be recorded and listened by students once again, or listened } \\
\text { by other people interested in that topic }\end{array}$ & $24(8.5)$ \\
\hline \multirow[t]{10}{*}{$50(17.6)$} & \multirow[t]{3}{*}{$27(9.5)$} & A lot of material for studies in one place, it is comfortable to find and use & $1(0.4)$ \\
\hline & & $\begin{array}{l}\text { All study material is given in the platform, where one can open and read at any } \\
\text { time }\end{array}$ & $1(0.4)$ \\
\hline & & $\begin{array}{l}\text { One can perform particular tasks more quickly - review video records, } \\
\text { soundtracks, read given information }\end{array}$ & $1(0.4)$ \\
\hline & \multirow{7}{*}{$\begin{array}{l}\text { Lecture organisation } \\
\text { smoothness } \\
23(8.1)\end{array}$} & Better communication with the lecturer, you are better heard, supported & $6(2.1)$ \\
\hline & & Lecturers put more effort preparing for lectures, give different types of activities & $5(1.8)$ \\
\hline & & Lecture material presentation is more diverse, one can use various apps & $3(1.0)$ \\
\hline & & Lecture absenteeism is smaller & $3(1.0)$ \\
\hline & & Study material acceptability is for a longer time & $2(0.7)$ \\
\hline & & During lectures I can surf the internet looking for extra material & $2(0.7)$ \\
\hline & & Quick information presentation and distribution and so on. & $2(0.7)$ \\
\hline \multirow{12}{*}{$\begin{array}{l}\text { Satisfaction } \\
\text { with the } \\
\text { studies } \\
49(17.3)\end{array}$} & \multirow{5}{*}{$\begin{array}{l}\text { Physical environment } \\
\text { suitability } \\
22(7.8)\end{array}$} & Bigger comfort & $8(2.8)$ \\
\hline & & Physical convenience, avoiding extra mobility, all necessary devices are at hand & $5(1.8)$ \\
\hline & & One can choose a comfortable working environment & $4(1.4)$ \\
\hline & & You can have coffee, tea during lectures, have a snack & $4(1.4)$ \\
\hline & & $\begin{array}{l}\text { You can choose the most convenient way of listening, i.e., during lectures you } \\
\text { can sit, stand }\end{array}$ & $1(0.4)$ \\
\hline & \multirow{3}{*}{$\begin{array}{l}\text { Reduction of fear and } \\
\text { stress } \\
17(6.0)\end{array}$} & Less stress, related to the environment change, because you stay at home & $12(4.2)$ \\
\hline & & Possibility to more concentrate, less tension & $3(1.0)$ \\
\hline & & There is no auditorium fear & $2(0.7)$ \\
\hline & \multirow{4}{*}{$\begin{array}{l}\text { Achievement } \\
\text { improvement } \\
10(3.5)\end{array}$} & Easier to learn & $5(1.8)$ \\
\hline & & Easier to account for various tasks & $3(1.0)$ \\
\hline & & Easier exams & $1(0.4)$ \\
\hline & & During online teaching, better results are achieved & $1(0.4)$ \\
\hline \multirow{7}{*}{$\begin{array}{l}\text { Improvement } \\
\text { of the } \\
\text { competencies } \\
20(7.0)\end{array}$} & \multirow{5}{*}{$\begin{array}{l}\text { General didactic ability } \\
\text { improvement } \\
10(3.5)\end{array}$} & Online studies strengthen the ability to learn independently & $4(1.4)$ \\
\hline & & $\begin{array}{l}\text { Possibility to deepen knowledge in various internet platform usage, information } \\
\text { is found faster }\end{array}$ & $2(0.7)$ \\
\hline & & Acquaintance with different types of learning tools & $2(0.7)$ \\
\hline & & More effective work in groups & $1(0.4)$ \\
\hline & & One can perform group tasks because most platforms are adapted to this & $1(0.4)$ \\
\hline & \multirow{2}{*}{$\begin{array}{l}\text { Technological literacy } \\
\text { improvement } \\
10(3.5)\end{array}$} & ICT abilities improve & $6(2.1)$ \\
\hline & & Computer literacy improvement & $4(1.4)$ \\
\hline
\end{tabular}

Note: Totally 284 semantic units were extracted 
In the second table, one can see that the category The convenience of studying has the highest weight (58.1\%), and Competence development - the lowest (7.0\%). The statements in the other two categories are fairly evenly distributed (Study process flexibility (17.6) and Satisfaction with the studies (17.3)).

Online teaching started during the pandemic has become a major advantage for the students seeking synergy between study and work. It must be assumed that work during the studies is quite popular because it is evidenced by more than a quarter of all statements received. The work provides students with both financial stability and valuable experience. Maintaining a balance between work and study while studying through contact would be rather complicated. Distance studies - is a very convenient option in this case, so more than a quarter of the significant statements testify about the possibility of combining studies and work.

Applying information communication technologies, the study process becomes accessible to almost everyone and from everywhere, all you need to do is to have a computer or a smartphone. Therefore, it is easy to combine participation in the lectures with the individual needs. One-seventh of the statements confirm that students enjoy attending lectures and at the same time being in a different environment, engaging in other subjects. It also does not go unnoticed that even being ill a student can participate in distance studies, which he would not allow in the case of contact activities. On the other hand, distance studies are also superior in that more students participate in lectures.

One-tenth of the statements confirm financial savings possibility that occurred as some students returned home and lived with their parents when the pandemic broke out. Therefore, they admit that they have less expenses, they do not have to rent an apartment, do not spend money on transport and so on. A small proportion of the statements fall into time planning sub-category. Students acknowledge that studying online they succeed in better time planning, easier making an agenda and sticking to it. So, there are less problems related to the time management.

The second, according to significance, is the category - Study process flexibility. With a more flexible study, students more easily respond to their needs, they are more active and more motivated study process participants. Thus, a sudden transition to distance learning also provided an opportunity to better respond to students' needs. Students are impressed by the availability of lecture content. They can view lecture recording at any time, find all the necessary information on the platform. It is convenient because everything is in one place. It has to be said that students acknowledge that organisation of lectures has become smoother. The statements testify that lecturers more seriously prepare for the lectures, use various apps, look for more diverse ways of conveying information, organise various activities, communicate with students. On the other hand, students are also more active, are less likely to miss the lectures. This allows to make a conclusion that during distance studies, the involvement of the participants in the study process gets better, deeper immersing into the study process.

The third category singled out is - satisfaction with the studies. Satisfaction in a general sense is understood as a feeling of happiness. It responds to what the person sought, what expected. As it is known, it is an important factor in evaluating studies. The mentioned category consists of three subcategories, the most significant of which is - physical environment suitability. Students like when working remotely they have a comfortable working environment, have necessary tools at hand, if they want, they can sip coffee or tea. Reduction of fear and stress - is one more singled out subcategory, which has got - only $6 \%$ statements. It turned out that during distance studies auditorium fear is reduced, you can be more focused, therefore, body tension decreases. Also, less stress is experienced because you are staying at home, in a normal environment. Achievement improvement - is a small subcategory, containing $3.5 \%$ of statements. Several students expressed the opinion that it is easier to study remotely, easier exams, easier to account for various tasks.

Two other not numerous categories as mentioned above general didactic ability improvement and technological literacy improvement have been merged into competence improvement category. And although not many significant statements this category combines, it has not gone unnoticed that the abilities of learning to learn, work in groups, ICT skills are developed during distance studies, one gets acquainted with various digital tools, platforms. 
Table 3. Online lecture disadvantages $N(\%)$

\begin{tabular}{|c|c|c|c|}
\hline Categories & Subcategories & Statements & $N(\%)$ \\
\hline \multirow{8}{*}{$\begin{array}{l}\text { Deterioration of } \\
\text { mental and } \\
\text { physical health } \\
82(27.7)\end{array}$} & $\begin{array}{l}\text { Negative effect on } \\
\text { mental health }\end{array}$ & $\begin{array}{l}\text { It is difficult to keep attention on the computer screen for a long time, it is } \\
\text { difficult to concentrate }\end{array}$ & $32(10.8)$ \\
\hline & $56(18.9)$ & During online lectures, fatigue, tiredness is felt, additional stress appears & $12(4.0)$ \\
\hline & & High lecture load per day, per week reduces concentration & $8(2.7)$ \\
\hline & & Dependence on the computer increases & $4(1.4)$ \\
\hline & Negative effect on & Physical tiredness & $12(4.0)$ \\
\hline & $\begin{array}{l}\text { physical health } \\
\mathrm{N}-26(8.8)\end{array}$ & $\begin{array}{l}\text { Eyesight gets worse when looking at computer screen for a long time, eye } \\
\text { strain symptoms occur }\end{array}$ & $10(3.4)$ \\
\hline & & You have to spend a lot of time at the computer, it's tiring & $2(0.7)$ \\
\hline & & Limited physical activity & $2(0.7)$ \\
\hline \multirow{6}{*}{$\begin{array}{l}\text { Non-realisation } \\
\text { of social needs } \\
73(24.7)\end{array}$} & Lack of & Lack of informal, real communication with colleagues & $24(8.1)$ \\
\hline & $\begin{array}{l}\text { communication } \\
44(14.9)\end{array}$ & $\begin{array}{l}\text { There is no communication, or it is limited between lectures, it is impossible to } \\
\text { make new contacts, friendships }\end{array}$ & $20(6.7)$ \\
\hline & Lack of socialisation & It is more difficult to make contact with lecturers, course friends & $10(3.4)$ \\
\hline & $29(9.8)$ & Lack of socialisation & $8(2.7)$ \\
\hline & & Lack of social connection, however, distance studies cannot replace contact & $8(2.7)$ \\
\hline & & $\begin{array}{l}\text { Social interaction between students, lecturers and students significantly } \\
\text { decreases }\end{array}$ & $3(1.0)$ \\
\hline \multirow{10}{*}{$\begin{array}{l}\text { Decline in the } \\
\text { involvement in } \\
\text { the study } \\
\text { process } \\
58(19.6)\end{array}$} & $\begin{array}{l}\text { The effect of side } \\
\text { stimuli }\end{array}$ & $\begin{array}{l}\text { It is very easy to deviate from the content of the lecture and immerse yourself } \\
\text { in side activities }\end{array}$ & $14(4.7)$ \\
\hline & $19(6.5)$ & Greater chance of distraction than being in an auditorium & $5(1.7)$ \\
\hline & Student apathy & Lower student participation in online lectures comparing with contact lectures & $5(1.7)$ \\
\hline & $17(5.7)$ & $\begin{array}{l}\text { During distance lectures students are more passive participants than learning } \\
\text { in traditional lectures }\end{array}$ & $5(1.7)$ \\
\hline & & Students are more sluggish than during regular lectures & $5(1.7)$ \\
\hline & & Students are much less likely to engage in discussion on an online platform & $2(0.7)$ \\
\hline & The increase in & High load, too much work to be done & $10(3.4)$ \\
\hline & $\begin{array}{l}\text { learning load } \\
16(5.4)\end{array}$ & The number of individual works is increasing & $6(2.0)$ \\
\hline & Deterioration of & Lack of motivation, decrease in receiving feedback & $4(1.4)$ \\
\hline & $\begin{array}{l}\text { motivation and } \\
\text { knowledge } \\
6(2.0)\end{array}$ & Knowledge deteriorates, as distance lectures are less inclusive, dry theory & $2(0.7)$ \\
\hline \multirow{11}{*}{$\begin{array}{l}\text { Deterioration of } \\
\text { the quality of } \\
\text { academic } \\
\text { activities } \\
56(18.9)\end{array}$} & Limitation of practical & There is less group work, discussions, they are limited & $16(5.4)$ \\
\hline & activities & It is difficult or impossible to carry out practical activities & $12(4.0)$ \\
\hline & $42(14.2)$ & There are few practical works, very much theory & $8(2.7)$ \\
\hline & & We cannot practically try a lot of methods, diversify lectures & $3(1.0)$ \\
\hline & & Performing team tasks is very complex & $2(0.7)$ \\
\hline & & Poor possibilities for realistic illustration & $1(0.3)$ \\
\hline & $\begin{array}{l}\text { Lack of lecturers' } \\
\text { competencies }\end{array}$ & $\begin{array}{l}\text { Some lecturers are not able to properly combine theoretical material and } \\
\text { practical tasks during the lectures }\end{array}$ & $4(1.4)$ \\
\hline & $14(4.7)$ & The "culture"/etiquette of distance teaching/learning is not high & $4(1.4)$ \\
\hline & & Lectures are often boring, there is no live communication & $3(1.0)$ \\
\hline & & $\begin{array}{l}\text { Distance lectures often take longer than usual, due to inability to arrange } \\
\text { everything or delays due to technical obstacles }\end{array}$ & $2(0.7)$ \\
\hline & & There are very few individual consultations, or they are not provided at all & $1(0.3)$ \\
\hline \multirow{4}{*}{$\begin{array}{l}\text { Organisational } \\
\text { technical } \\
\text { disorders } \\
27(9.1)\end{array}$} & Technical disorders & Not always a proper internet connection, various technical disorders & $20(6.7)$ \\
\hline & $22(7.4)$ & $\begin{array}{l}\text { Exams and assessments sometimes cause bigger stress due to fear and that } \\
\text { some technical problems can emerge }\end{array}$ & $2(0.7)$ \\
\hline & $\begin{array}{l}\text { Study and work } \\
\text { combination }\end{array}$ & $\begin{array}{l}\text { It is more difficult to create an agenda, especially when you have also to } \\
\text { combine distance work }\end{array}$ & $3(1.0)$ \\
\hline & $\begin{array}{l}\text { difficulties } \\
5(1.7)\end{array}$ & It is very difficult to combine work, studies and family matters & $2(0.7)$ \\
\hline
\end{tabular}

Note: Totally 296 semantic units were extracted

Online lecture disadvantages perceived by students were also analysed. On the basis of semantic analysis, five subcategories were extracted: Deterioration in mental and physical health, Non-realisation of social needs, Decline in the involvement in the study process, Deterioration of the quality of academic activities, and Organisational-technical disorders. The results are presented in Table 3. 
In Table 3, one can see that there is no single clearly predominant category, except for the one with the lowest weight - Organisational-technical disorders (9.1\%). The categories Deterioration of physical and mental health (27.7\%) and Non-realisation of social needs (24.7\%) have the largest weight. These categories account for more than half of all statements, the other two categories are almost equal in terms of significance: Deterioration in the involvement in the study process (19.6) and Deterioration of the quality of academic activities (18.9\%).

As it is known, more than in a quarter of statements was mentioned Deterioration of mental and physical health. If we analyse which health - mental or physical - students complain more about, we would see that the negative effects of distance learning on mental health were twice as common. Students name increasing fatigue, exhaustion, poorer concentration of attention, appearing stress, and so on. Negative effect on physical health manifests itself through the decreased physical activity, physical fatigue, excessive strain on the eyes.

Students participating in the research express their thoughts on unrealised social needs. Young people experience lack of communication (there is lack of communication with colleagues, exchange of opinions, etc.). They acknowledge that distance learning makes it difficult to make friends and make new contacts. The other subcategory includes statements about lack of socialisation. Students notice a decrease in social interaction with both lecturers and students. Without direct communication, part of social interaction means, it is understandable, no longer play their role. No opportunity was left to observe the other people's behaviour, learn to adapt, complement each other and so on.

About one-fifth of the statements indicate decline in the involvement in the study process. The statements related to this category are divided into four subcategories. One of them- the effect of side stimuli. The identified statements justify the possibility to deviate from the study process, the examined content, and to engage in less significant activities. A slightly smaller proportion of statements is attributed to student apathy. They show that students in distance lectures are more passive, more sluggish than in contact lectures. The reasons for this shortcoming may be a little deeper. During the pandemic, no active leisure time is left for students, the environment interests less and less, and over a longer period of time, passiveness, apathy can be passed on to the study process. Of course, it is not very good if due to these reasons, also suffers the student's ability to work. The other subcategory - the increase in learning load shows that the number of independent work tasks, which have to be performed in virtual environment, has increased for students. The fourth subcategory - deterioration of motivation and knowledge - does not have many statements, however, it is also worth discussion. Students see a threat to their knowledge. Without sufficient feedback, dry theory dominating, it is difficult not to lose motivation to learn.

Speaking about the deterioration of the quality of academic activities, two subcategories were distinguished. The first - limitations of practical activities. It combines the statements about the decrease of practical works, or that they cannot be performed under distance learning conditions. Also, it is regretful that theoretical discussions occupied the place of practical activities. A lack of discussions and teamwork is mentioned, and a lack of visual aids in the activities. The latter subcategory is three times bigger by her statements than the second one - lack of lecturers' competencies. Students notice that lecturers do not try to combine theory with practice, activities are boring, non-engaging, sometimes take longer. They lack live communication and individual consultations.

Less than one tenth of statements covers the fifth category - organisational - technical disorders. From the subcategory of technical problems equipment, internet hindrances are mentioned and rising fears that technologies work well during the assignments and exams. The subcategory that is of minor significance study and work combination difficulties covers the statements, in which students speak openly about problems arising combining distance work, distance studies, and family matters.

The positions of the respondents regarding the possibilities of improving distance lectures were analysed. Four main categories were extracted: Planning and organisation improvement, Lecture design improvement, Communication skill improvement, Study process management improvement. The results are presented Table 4. 
Table 4. Online lecture improvement (suggestions, recommendations) $N(\%)$

\begin{tabular}{|c|c|c|c|}
\hline Categories & Subcategories & Statements & $N(\%)$ \\
\hline \multirow{8}{*}{$\begin{array}{l}\text { Planning and } \\
\text { organisation } \\
\text { improvement } \\
50(30.7)\end{array}$} & \multirow{4}{*}{$\begin{array}{l}\text { Study content } \\
\text { optimisation } \\
36(22.1)\end{array}$} & Record lessons and present to students & $15(9.3)$ \\
\hline & & $\begin{array}{l}\text { Theoretical material can also be presented in videos that can be viewed } \\
\text { independently }\end{array}$ & $14(8.6)$ \\
\hline & & $\begin{array}{l}\text { Part of the study material (theory) could be presented earlier, and analysed } \\
\text { during the lectures }\end{array}$ & $5(3.1)$ \\
\hline & & More flexibly adapt study tasks for distance learning & $2(1.2)$ \\
\hline & \multirow{4}{*}{$\begin{array}{l}\text { Searching for harmony } \\
\text { of study methods } \\
9(5.5) \\
\text { Searching for theory } \\
\text { and practice harmony } \\
5(3.1)\end{array}$} & Organise not only theoretical but also practical parts in distance learning & $6(3.7)$ \\
\hline & & Combine distance lectures with regular ones & $3(1.8)$ \\
\hline & & $\begin{array}{l}\text { Think about, reconcile the presentation of theoretical material and practical } \\
\text { tasks to get the right balance }\end{array}$ & $3(1.8)$ \\
\hline & & $\begin{array}{l}\text { Look through the lecture content and tasks, adapt them to better meet the } \\
\text { specifics of distance lectures }\end{array}$ & $2(1.2)$ \\
\hline \multirow{9}{*}{$\begin{array}{l}\text { Study process } \\
\text { management } \\
\text { improvement } \\
43(26.4)\end{array}$} & \multirow{6}{*}{$\begin{array}{l}\text { Organization } \\
\text { improvement } \\
37(22.7)\end{array}$} & $\begin{array}{l}\text { There should be not more than } 4 \text { lectures a day, as constant work at the } \\
\text { computer is very frustrating }\end{array}$ & $10(6.1)$ \\
\hline & & Shorten direct contact hours, so you don't have to sit long at a computer screen & $8(4.9)$ \\
\hline & & Devote more time for individual - independent student work & $8(4.9)$ \\
\hline & & Longer breaks are necessary between lectures & $6(3.7)$ \\
\hline & & Lectures must last the specified time and have breaks & $5(3.1)$ \\
\hline & & More purposefully plan the time of the lectures & $2(1.2)$ \\
\hline & \multirow{2}{*}{$\begin{array}{l}\text { Increasing the } \\
\text { responsibility of } \\
\text { academic staff } \\
5(3.1)\end{array}$} & $\begin{array}{l}\text { Lecturers should be able to better use programmes, to take advantage of more } \\
\text { virtual opportunities }\end{array}$ & $4(2.5)$ \\
\hline & & Strengthen student discipline & $1(0.6)$ \\
\hline & $\begin{array}{l}\text { Ensuring internet } \\
\text { connection } \\
1(0.6) \\
\end{array}$ & Ensure better internet connection for lecturers and students & $1(0.6)$ \\
\hline \multirow{9}{*}{$\begin{array}{l}\text { Lecture design } \\
\text { improvement } \\
35(21.5)\end{array}$} & \multirow{4}{*}{$\begin{array}{l}\text { Ensuring the diversity } \\
\text { of methods and } \\
\text { activities } \\
20(12.3)\end{array}$} & More practical tasks/ try to integrate more practical activities & $8(4.9)$ \\
\hline & & More group/teamwork & $6(3.7)$ \\
\hline & & Lectures must be in an attractive format and form & $5(3.1)$ \\
\hline & & Apply active teaching methods & $1(0.6)$ \\
\hline & \multirow{5}{*}{$\begin{array}{l}\text { Increasing the } \\
\text { technology / } \\
\text { visualisation of the } \\
\text { lecture process } \\
15(9.2)\end{array}$} & Include more smart technologies, various apps & $5(3.1)$ \\
\hline & & Find alternative programmes, which "would enliven" distance lectures & $4(2.5)$ \\
\hline & & $\begin{array}{l}\text { Include in lectures documentaries, educational, etc. film screenings (according to } \\
\text { the studied specialty) }\end{array}$ & $4(2.5)$ \\
\hline & & There could be some virtual trips (museums, virtual meetings). & $1(0.6)$ \\
\hline & & Use other platforms to diversify lecture content & $1(0.6)$ \\
\hline \multirow{6}{*}{$\begin{array}{l}\text { Communication } \\
\text { skill } \\
\text { improvement } \\
33(20.2)\end{array}$} & \multirow{3}{*}{$\begin{array}{l}\text { Communication and } \\
\text { collaboration } \\
\text { encouragement } \\
17(10.4)\end{array}$} & Make possibilities for students to collaborate with each other & $11(6.7)$ \\
\hline & & Strengthen student communication and collaboration & $3(1.8)$ \\
\hline & & Build a closer relationship with students, by providing more frequent feedback & $3(1.8)$ \\
\hline & \multirow{3}{*}{$\begin{array}{l}\text { Promoting student } \\
\text { involvement/activity } \\
16(9.8)\end{array}$} & $\begin{array}{l}\text { Give lectures to smaller groups of students so that everyone can speak and be } \\
\text { heard }\end{array}$ & $7(4.3)$ \\
\hline & & More discussions, encourage discussions among participants & $6(3.7)$ \\
\hline & & Provide opportunity for all students to speak during seminars & $3(1.8)$ \\
\hline
\end{tabular}

Note: Totally 163 semantic units were extracted

As can be seen in Table 4, more than half of the weight is given to categories Planning and organisation improvement (30.7\%) and Study process management and improvement (26.5\%). The other two categories Lecture design improvement (21.5\%) and Communication skill improvement (20.2\%) are slightly inferior, however of a similar value between themselves.

The most significant category in Planning and organisation improvement is Study content optimization. It accounted for as much as one-fifth of all statements received in this regard. Students provide valuable advice. They would like all the lectures to be recorded and submitted recordings to be reviewed independently or obtained before practical activities to get acquainted so that the content can be analysed and discussed during activities. It has to be said that these are quite rational proposals. This is the principle of "blended" teaching, when a student studies the theoretical part independently, and then a discussion is organised to 
discuss the theoretical material, to establish the most important things. In addition, students would like tasks for distance learning to be more flexibly adapted.

Some of the statements fell into small subcategories Searching for the harmony of study methods and Searching for the harmony of theory and practice. In the first case, it is recommended to pay more attention to the practical part of the study subjects, and it is desired that the distance lectures be combined with the usual ones (though it was not possible under quarantine conditions). In the second case, more optimal theory and practical part balance is desired, suitable tasks prepared for distance learning.

A quarter of the valuable recommendations are combined into the Study process management improvement. This category has a particularly significant subcategory Organisation improvement, where students' suggestions are assigned for making a schedule because according to them, it is very difficult to sit at the computer screen for 8 hours. It is proposed to review study programmes and, if possible, to increase the number of independent work hours. By increasing the responsibility of academic staff, students recommend taking responsibility for student discipline strengthening and suggest improving the ability to use various apps.

The category Lecture design improvement consists of two subcategories. The first, Ensuring the diversity of methods and activities highlights the students' desire to have more group/teamwork and practical activities. So, it would be possible to ensure synergy between theory and practice. In addition, a more interesting, more inclusive lecture format based on active teaching/learning methods is expected. The statements included in the second category responded to the Increase in the lecture process technologization /visualisation. Students offer to use the possibilities of various platforms in the lectures, to use more digital apps, virtual trips to the discussed objects, and to make use of the video material for lecture content diversity.

One-fifth of the statements fell into Communication skill strengthening category. Two roughly equal categories were distinguished here. The first is - Communication and collaboration encouragement. Students recommend creating opportunities for them to communicate and collaborate during sessions, to build a closer relationship between the lecturer and the student, even though by providing him/her with more frequent feedback. The second one - Promoting student engagement/activity includes statements about discussions, lectures for smaller groups of students, where they would have more opportunities to speak, express opinions and so on.

\section{DISCUSSION}

The aim of the research was to find out what advantages and disadvantages are seen by university students, as well as to reveal probable similarities between regular and distance lectures. Also, it was sought to analyse distance lecture improvement possibilities. This is especially important in the planning, organisation, and management aspects of the study process. It is important not to forget that the research study was conducted during COVID-19 pandemic, in other words, the students having participated in the study, studied normally, but during the pandemic virtually the entire study process moved to electronic space i.e., at the same time it became online learning and distance learning. Distance learning can be considered as an integral field of two sciences - pedagogy and informatics. Therefore, the functions of distance learning can be relatively divided into two groups - pedagogical (didactic) and technological.

Analysing the advantages of distance lectures, it is obvious that the category with the greatest weight was "The convenience of studying" (58.1\%). This is not an unexpected result because it is a common advantage of distance studies. With the rapid change of ICT, the study process is also changing rapidly. Researchers notice that technological lifestyle is a self-evident reality, in which information and its management are not only the dominant value, but also an important need of the present man (Melnikovas, 2017). Not only nowadays, but in future as well, ICT have to be attractive for the students, comfortable to see for the teachers and lecturers. In addition, it should be specially made for teaching/learning purposes. Selection process problem, in didactics respect, will get more acute, because market (producers') pressure on education system will, undoubtedly, increase (Lamanauskas, 2013). As Čiarnienè et al. (2012) noted although 
computerised and distance teaching networks have been created in Lithuania, distance learning courses are being created, students still do not sufficiently use the opportunities and peculiarities of IT and distance learning. However, as it was already mentioned, in the conditions of pandemic, the need of distance learning has increased to the maximum. The research results allow stating that the convenience of studying students treat as a possibility to combine work and studies, as well as combining participation in the lectures with individual needs. This confirms the results of the previous conducted research in Lithuania, stating that online learning is very suitable for working students as a possibility to combine work and studies (Tankelevičienè \& Turskiene, 2003). The research studies conducted by other researchers during the pandemic also highlight such advantages as flexibility, accessibility, and comfort (Mukhtar et al., 2020). A perfectly understandable argument for financial saving. This confirms the statements of the previous research that the overall costs of distance education are actually lower than those of traditional education (Oliveira et al., 2018), such format allows saving finances or even make possibilities to study for those, who wouldn't be able to do this due to financial reasons (Brown, 2017; Sadeghi, 2019). The obtained results practically confirm the results of the previous research studies conducted in Lithuania that reducing students' transport costs, possibility to multitask, concentration, not absent mindedness, constructive communication with peers, quality consultations are relevant (Vilkonis et al., 2014). Also, the results of the study fully correlate with the latest study of the same format conducted in Romania, where the main advantages were found to be time-saving, comfort, and money-saving (Manea et al., 2021).

Analysing the shortcomings of distance lectures one can see that basically they are twofold. One distinguished category reflects physical and mental health deterioration (27.7\%), the other the nonrealisation of social needs (24.7\%). Basically, this correlates with general negative things about the use of ICT, such as long time working on computer, low physical activity, fatigue and even computer addiction. This is also confirmed by the results of the previous studies stating that the excessive use may lead to addiction (Lamanauskas et al., 2017). The obtained results also highlight shortcomings as reduced involvement in the study process, deterioration of motivation and knowledge, and finally deterioration of the quality of academic activities in general. Essentially, similar deficiencies are also revealed by Mukhtar et al. (2020) research, revealing such fundamental shortcomings as inefficiency and difficulty in maintaining academic integrity. Once again it is important to emphasize that not only online teaching (learning), but also distance learning is analysed. In 2009, a research in Australia was conducted with students from remote locations around the country who had studied at an Australian university between 2003 through 2007. The research revealed such essential shortcomings as feeling isolated, missing face-to-face contact with staff, and lacking confidence in managing the technology associated with study (Owens et al., 2009). Sadeghi (2019) research showed that students studying alone may feel isolated, and also miss the social physical interaction.

It is obvious that distance learning (distance lectures in this case) has to be improved seeking maximum efficiency and study quality. The conducted research showed that the main focus should be on improving the planning and organisation of the study process as well on improving lecture design. Various previous studies emphasize that lecturers should prepare better teaching material with higher prospects of success (Dzakiria, 2004). Based on the research results, it can be unequivocally stated that students need various support while learning including physical resources and lecturer support. This reaffirms Pratt's (2015) position that there are indeed many areas, where serious improvements could be made.

However, distance learning should be seen in another aspect - according to the changing roles of the student and the lecturer in the learning process. Here, as in organising contact process, it is possible to distinguish the same three prevailing paradigms - teaching, learning, self-directed learning.

The study has some limitations. First of all, a qualitative, limited study was conducted. Research parameters are not analysed in terms of gender, field of study and direction. In order to better understand the situation, university lecturer position research would be useful. It is obvious that the responsibility and the role of a distance learning lecturer in the development of teaching materials and performing the tasks of a particular course has significantly increased (Miščenko, 2014). On the other hand, the majority of the respondents consisted of the social sciences study programmes, i.e., future teachers. The study did not cover students of natural sciences, technologies, mathematics study programmes. Despite these limitations, the study 
revealed the obvious advantages and disadvantages of distance learning and the possibilities to improve university study process performed in an online and/or distance format. The research results are most extrapolated in the field of social sciences. The acquired knowledge enables the lecturers to choose and combine teaching methods, forms, tools and methods in a more meaningful way, to constantly monitor and respect the individual differences and needs of students in distance learning. In further research it would be rational to combine quantitative with qualitative research methods, which contribute to gaining a more complete insight into the researched area.

As mentioned earlier, the focus was on content delivery, so systematic, attractive and adaptive content was not a priority. The essential thing was to ensure the continuation of the study process. Distance teaching/learning that started during the pandemic greatly accelerated the development of lecturers' ICT skills, and universities rapidly began to implement special tools to improve the quality of distance learning. In order to ensure the effectiveness of distance learning, both students and teachers need appropriate training on how to facilitate the study process through the use of various ICTs (Nsengimana et al., 2021).

\section{CONCLUSIONS AND IMPLICATIONS}

Based on the results of the research, it can be stated that distance lectures have obvious advantages. Convenience of studying has been highlighted as a key advantage because students have better possibilities to combine studies with work and personal needs; also, distance learning has led to financial savings, which is always relevant for students. Students value the flexibility of the studies i.e., notice lecturers' work and efforts ensuring the smoothness of the study process. They appreciate that the content of distance lectures is recorded and available to them at any time. Satisfaction with the studies is associated with the comfort of studying: a comfortable home environment, reduction of fear and stress and improving achievements. It can be said that transition to distance learning has opened new opportunities to improve general and didactic abilities, technological literacy.

Undoubtedly, certain shortcomings of distance lectures have been highlighted. It turned out that students feel the deterioration of physical and mental health, the negative effects of distance lectures on mental health are noticeable; spending a lot of time at computer screens, of course, also worsens physical health. Distance learning has deprived students of the opportunity to realise their social needs - students feel a lack of communication, have no possibilities to socialise, or these are very poor. On the other hand, students' involvement in the study process deteriorates, as the learning load increases, at the same time knowledge deteriorates, motivation decreases, apathy appears. A negative consequence is evident, i.e., the quality of academic activities deteriorates, which is primarily manifested through practical barriers, prevailing theoretical activities, or lack of competence of lecturers in mastering the challenges of distance learning.

Seeking to improve the quality of distance learning, several aspects should be noted. This is firstly related to planning and organisation improvement. Better results could be achieved by optimising the study content, looking for a closer dialogue between study methods and coherence between theory and practice. Study process management improvement is seen as a second improvement direction. This could be done starting with the revision/changes of the study plan and ending with the creation of the lecture schedule, and the increase of the responsibility of the academic staff (improvement of competencies, strengthening of student discipline). A particularly significant aspect is lecture design improvement in a general sense. This is related to ensuring the diversity of methods and activities and increasing the visualisation of lectures. Equally important is the strengthening of communication skills, i.e., promoting communication and collaboration (although limited, but also possible through distance learning) and increasing student involvement in the study process.

The planning and organization of the study process should be more flexible and efficient, taking into account various possible situations. University lecturers should be encouraged to be more creative and learn more advanced teaching methods, to develop information technology management skills. In addition, they must be provided with ongoing methodological and technical assistance. 
Author contributions: All authors were involved in concept, design, collection of data, interpretation, writing, and critically revising the article. All authors approve final version of the article.

Funding: The authors received no financial support for the research and/or authorship of this article.

Declaration of interest: Authors declare no competing interest.

Data availability: Data generated or analysed during this study are available from the authors on request.

Acknowledgements: The authors would like to thank all students who participated in the research.

\section{REFERENCES}

Atadjanov, H. (2020). Students' motivation and independent work of students in an online and blended learning environment. Central Asian Problems of Modern Science and Education, 1, Article 8.

Ballova Mikuškova, E., \& Verešova, M. (2020). Distance education during COVID-19: The perspective of Slovak teachers. Problems of Education in the $21^{\text {st }}$ Century, 78(6), 884-906. https://doi.org/10.33225/pec/20.78.884

Berkova, K., Boruvkova, J., Frendlovska, D., Krpalek, P., \& Melas, D. (2020). Learning style preferences of university and college students. Problems of Education in the $21^{\text {st }}$ Century, 78(4), 486-499. https://doi.org/10.33225/pec/20.78.486

Bitinas, B. (2002). Pedagoginès diagnostikos pagrindai [Basics of pedagogical diagnostics]. Vilniaus pedagoginio universiteto leidykla.

Borisova, O. V., Vasbieva, D. G., Malykh, N. I., Vasnev, S. A., \& Bírová, J. (2016). Problem of using innovative teaching methods for distance learning students. International Electronic Journal of Mathematics Education, 11(5), 1175-1184.

Brown, C. (2017). Advantages and disadvantages of distance learning. ezTalks. https://www.eztalks.com/elearning/advantages-and-disadvantages-of-distance-learning.html

Brown, M., Hughes, H., Keppell, M., Hard, N., \& Smith, L. (2015). Stories from students in their first semester of distance learning. International Review of Research in Open and Distributed Learning, 16(4), 1-17. https://doi.org/10.19173/irrodl.v16i4.1647

Čiarnienė, R., Vienažindienė, M., \& Kumpikaitè, V. (2012). Informacinių technologijų taikymas studijų procese: palyginamoji analize [Application of information technologies in the study process: Comparative analysis]. Economics and Management, 17(4), 1552-1558. https://doi.org/10.5755/j01.em.17.4.3028

Cohen, L., Manion, L., \& Morrison, K. (2000). Research methods in education. Taylor \& Francis Group, RoutledgeFalmer.

Creswell, J. (1998). Qualitative inquiry and research design: Choosing among five traditions. Sage.

Dzakiria, H., Razak, A. A., \& Mohamed, A. H. (2004). Improving distance courses: Understanding teacher trainees and their learning styles for the design of teacher training courses and materials at a distance. Turkish Online Journal of Distance Education-TOJDE, 5(1), 2-17. https://dergipark.org.tr/en/pub/tojde/issue/16931/176752

Klapproth, F., Federkeil, L., Heinschke, F., \& Jungmann, T. (2020). Teachers' experiences of stress and their coping strategies during COVID-19 induced distance teaching. Journal of Pedagogical Research, 4(4), 444-452. https://doi.org/10.33902/JPR.2020062805

Konariovas, A. (2014). Mokymosi proceso veiksmingumo didinimas taikant nuotolinio mokymo technologijas [Development the effectiveness of the learning process applying the technologies of distance learning] (Master's Thesis). Kauno Technologijos Universitetas. https://epubl.ktu.edu/object/elaba:2174781/ 
Lamanauskas, V. (2013). Information communication technologies, education quality and challenges for future. Problems of Education in the 21st Century, 56, 5-7. http://www.scientiasocialis.lt/pec/node/849

Lamanauskas, V., lordache, D. D., \& Pribeanu, C. (2017). Social influence and dependence in the Facebook use by Romanian and Lithuanian university students. Problems of Education in the 21st Century, 75(4), 354-365. https://doi.org/10.33225/pec/17.75.354

Leontyeva, I. A. (2018). Modern distance learning technologies in higher education: Introduction problems. EURASIA Journal of Mathematics, Science and Technology Education, 14(10), Article em1578. https://doi.org/10.29333/ejmste/92284

Louis-Jean, J., \& Cenat, K. (2020). Beyond the face-to-face learning: A contextual analysis. Pedagogical Research, 5(4), em0077. https://doi.org/10.29333/pr/8466

Manea, V. I., Macavei, T., \& Pribeanu, C. (2021). Perceived benefits of online lectures during the pandemic: A case study in engineering education. Pro Edu. International Journal of Educational Sciences, 3(4), 3541. https://doi.org/10.26520/peijes.2021.4.3.35-41

Melnikovas, A. (2017). Nuotolinio mokymo funkcijų genezè technologinio ir edukacinio virsmo paradigmy kontekstuose [The genesis of distance education functions within the contextual conversion of technological and educational paradigms]. Tiltai, 1, 113-126. https://doi.org/10.15181/tbb.v76i1.1517

Merriam, S. B. (1998). Qualitative research and case study applications in education. Jossey-Bass Publishers.

Miles, M. B., \& Huberman, A. M. (1994). Qualitative data analysis (2nd Ed.). Sage Pub.

Miščenko, O. (2014). Dėstytojo esminè svarba dėstant nuotoliniu būdu ir progresyvusis mokymo metodas, naudojant virtualiąją mokymo aplinką [The importance of a teacher in a distance education and the progressive methods of teaching in a virtual learning environment]. SANTALKA: Filologija, Edukologija /COACTIVITY: Philology, Educology, 22(2), 97-104. https://doi.org/10.3846/cpe.2014.010

Morse, J. M. (1994). Designing funded qualitative research. In Denizin, N. K. \& Lincoln, Y. S., Handbook of qualitative research (2nd Ed). Sage.

Mukhtar, K., Javed, K., Arooj, M., \& Sethi, A. (2020). Advantages, limitations and reommendations for online learning during COVID-19 pandemic era. Pakistan Journal of Medical Sciences, 36(COVID-19-S4), 2731. https://doi.org/10.12669/pjms.36.COVID-19-S4.2785

Navickienè, V., \& Vainorytė, B. (2015). Lietuvos kolegijų nuotolinių studijų e. mokymosi formų ir priemonių analizè [Analysis of E-learning forms and aids of distance studies in Lithuanian colleges]. Pedagogika, 120, 73-88. https://doi.org/10.15823/p.2015.039

Neuman, W. L. (1997). Social research methods: Qualitative and quantitative approaches (3rd ed.). Allyn and Bacon.

Nsengimana, T., Bazimaziki, G., Nyirahabimana, A., Mushimiyimana, J. B., Mutarutinya, V., Mugabo, L. R., \& Nsengimana, V. (2021). Online Learning during COVID-19 pandemic in Rwanda: Experience of postgraduate students on language of instruction, mathematics and science education. Contemporary Mathematics and Science Education, 2(1), ep21009. https://doi.org/10.30935/conmaths/10788

Oliveira, M. M. S., Penedo, A. S. T., \& Pereira, V. S. (2018). Distance education: Advantages and disadvantages of the point of view of education and society. Dialogia, 29, 139-152. https://doi.org/10.5585/Dialogia.n29.7661

Owens, J., Hardcastle, L., \& Richardson, B. (2009). Learning from a distance: The experience of remote students. Journal of Distance Education, 23(3), 53-74. http://hdl.handle.net/10536/DRO/DU:30021696 
Pratt, K. (2015). Supporting distance learners: Making practice more effective. Journal of Open, Flexible and Distance Learning, 19(1), 12-26. https://files.eric.ed.gov/fulltext/EJ1068330.pdf

Qureshi, E., Morton, L. L., \& Antosz, E. (2002). An interesting profile-university students who take distance education courses show weaker motivation than on-campus students. Online Journal of Distance Learning Administration, 5(4). https://www.westga.edu/ distance/ojdla/winter54/Quershi54.htm

Rutkauskienė D., \& Pociūtė E. (2006). Virtualaus mokymosi modeliai [Virtual learning models]. KTU.

Sadeghi, M. (2019). A shift from classroom to distance learning: Advantages and limitations. International Journal of Research in English Education, 4(1), 80-88. https://doi.org/10.29252/ijree.4.1.80

Samašonok, K., \& Žonych, A. (2020). Nuotolinès studijos: neišvengiamybė, iššūkiai ir tobulinimo galimybès [Distance study: Inevitability, challenges and opportunities for improvement]. Science \& Processes of Education / Mokslas ir Edukaciniai Procesai, 2, 23-35.

Stankūnienè, R. (2012). Nuotolinès paskaitos kūrimas panaudojant įrankị "Lesson" Moodle sistemoje [Lectures using distance building tool to "Lesson" Moodle]. https://core.ac.uk/download/pdf/62656593.pdf

Tankelevičienė, L., Turskienè, S. (2003). Moksleivių ir studentų nuostatų i nuotolines studijas tyrimas [Research on attitudes of pupils and students towards distance learning]. Pedagogika, 69, 223-229.

Torres-Gastelu, C. A. (2021). Late adoption of preventive measures of online privacy in Mexican and Colombian university students. Problems of Education in the $21^{\text {st }}$ Century, 79(1), 162-184. https://doi.org/10.33225/pec/21.79.162

Tuychieva, S. M., Nematova, G. A. \& Arzikulov, M. U. (2020). Innovative methods for distance learning. Central Asian Journal of Education, 5(2), Article 8. https://uzjournals.edu.uz/cjedu/vol5/iss2/8

Vilkonis, R., Turskienè, S., \& Barabanova, I. (2014). Informacinių ir komunikacinių technologijų panaudojimo mokantis savarankiškai privalumai: universiteto studentų ir gimnazijos mokinių nuomonių lyginamoji analizè [Benefits of the use of ICT for autonomous learning: Comparative analysis of university and high school students' opinion]. Jaunujy mokslininky darbai, 2(42), 75-82. https://etalpykla.lituanistikadb.It/object/LT-LDB-0001:J.04 2014 1486561312123/

Wu, P., Low, S.-P., Liu, J.-Y., Pienaar, J., \& Xia, B. (2015). Critical success factors in distance learning construction programs at Central Queensland University: Students' perspective. Journal of Professional Issues in Engineering Education and Practice, 141(1), Article 0000217. https://doi.org/10.1061/(ASCE)El.1943-5541.0000217

Yildırım, A., \& Şimşek, H. (2011). Sosyal Bilimlerde Nitel Araştırma Yöntemleri (8 ${ }^{\text {th }}$ Edition) [Qualitative research methods in the social sciences]. Seçkin Publishing.

Zaborova, E. N., Glazkova, I. G., \& Markova, T. L. (2017). Distance learning: Students' perspective. Sotsiologicheskie issledovaniya [Sociological Studies], 2, 131-139.

Correspondence: Vincentas Lamanauskas, Vilnius University Šiauliai Academy, Lithuania.

E-mail: vincentaslamanauskas@yahoo.com 